\title{
Instructional Support for the Teaching of Critical Thinking: Looking Beyond the Red Brick Walls
}

\author{
Nancy Bowers, PhD \\ Instructor of Biology \\ Park University
}

Many instructors appreciate the importance of developing the critical thinking skills of their students yet are unfamiliar with pedagogical approaches for teaching critical thinking. These instructors rely on instructional support from teaching and learning centers or online resources. It can be time consuming, however, for instructors to translate generic teaching strategies into actual lessons related to their course content. The purpose of this paper is to review an under-utilized source of discipline-specific instructional resources for teaching critical thinking: professional organizations. Many national organizations support education within their discipline

by providing a variety of instructional materials, pedagogical approaches and a

venue for sharing teaching tips and lessons by their members. Hundreds of professional organizations across dozens of disciplines were examined to determine the types of instructional support provided. Representative teaching resources from these organizations are documented from a variety of disciplinary areas.

\section{Introduction}

In our everyday lives we are faced with decisions that require reasoning, understanding, correlation, interpretation and synthesis. All college graduates are expected to be critical thinkers, enabling them to make complex decisions swiftly, act ethically, respect the ideas of others and be adaptable in the face of change. Despite the importance that society and higher education put on critical thinking, Paul et al. (1997) found that while $89 \%$ of faculty interviewed said that critical thinking was one of their primary teaching goals, only $19 \%$ could provide a definition of critical thinking. It turns out that critical thinking is a complex concept that consists of multi-dimensional constructs involving both cognitive skills and affective dispositions, so it is not surprising that many instructors are unsure about how to teach their students to think critically. Numerous definitions for critical thinking exist, but for the purpose of this paper, Huitt's (1998) definition, since it is generic enough to be useful by all disciplines, will be used: "Critical thinking is the disciplined mental activity of evaluating arguments or propositions and making judgments that can guide the development of beliefs and taking action".

It might seem convenient to direct students to courses specifically designed to teach critical thinking skills, yet many studies suggest that the development of these skills is best done in association with specific content or within a domain of knowledge (Raths et al. 1967, Ennis 1990). Therefore, the teaching of critical thinking should be integrated into in all courses and in all classroom areas: lectures, discussions, homework, writing assignments, and exams. To be successful critical thinkers, students must become proficient in certain cognitive skills (e.g., interpretation, analysis, evaluation, inference, explanation, self-regulation) as well as develop dispositions towards critical thinking (e.g., inquisitiveness, openmindedness, self-confidence, systematicity, analyticity, truth-seeking, judiciousness) (Facione 2006). Numerous instructional approaches can be used to encourage critical thinking in students, such as the development of study skills, use of creative and critical thinking skills (e.g., problem solving, exploration), meta- 
cognition, inquiry training, and the asking of higher-order questions (Cotton 1991). Since many college instructors have no formal training in how to teach critical thinking, however, they will need support in developing effective learning activities to cultivate the critical thinking skills of their students.

Some colleges are fortunate to have an office or center responsible for providing pedagogical support, such as the Center for Excellence in Teaching and Learning (CETL) at Park University. There are also ample online resources that deal specifically with critical thinking (see Peirce 2004), major institutional initiatives (e.g., WSU's Critical Thinking Project) and organizations dedicated to critical thinking (e.g., The Critical Thinking Community). A number of commercial ventures (e.g., InSight Assessment) have developed standardized critical thinking assessment tools that many

Since many college instructors have no formal training in how to teach critical thinking, however, they will need support in developing effective learning activities to cultivate the critical thinking skills of their students.

institutions use. Instructors, however, would benefit the most by having access to discipline-specific learning activities that they can seamlessly integrate into their courses. One potential source that many instructors may be unaware of is the discipline-specific professional organizations to which many may belong. A number (but not all) of these large, national organizations have made a commitment to the support of teaching within their discipline, as evidenced by a standing committee or division that specifically addresses educational issues. Instructional support may take the form of a publication specifically dedicated to education, the informal sharing of teaching materials among members, or the integration of a section within the research journal that provides educational tips and learning activities. Because of the recognized importance of critical thinking, much of these teaching materials directly or indirectly support the teaching of critical thinking skills.

This paper reports on a review of hundreds of professional organizations representative of most major branches of learning in order to evaluate the extent to which these organizations support teaching within their discipline. A number of the professional organizations reviewed either did not offer instructional support or restricted access to much of their materials. Those that did provide freely available resources often offered many types of support. It is beyond the scope of this paper to report on all of the

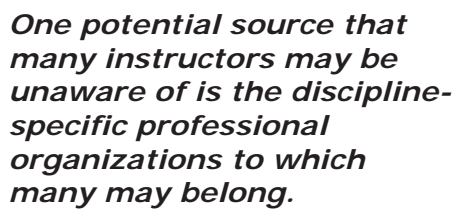
possible resources, so for each organization, a representative instructional resource is reviewed and a specific example provided. Not all disciplines are represented nor all organizations; the purpose is to illustrate what instructors can look for in their own professional organization.

For the purpose of this paper, disciplines have been grouped into five major categories: arts and humanities (e.g., art and design, communication arts, English, history, modern languages, music, philosophy), business (e.g., accounting, economics, finance, management, marketing), education, natural and applied sciences (e.g., biology, chemistry, computer science, geology, mathematics, physics), and social sciences (e.g., criminal justice, political science, psychology, sociology, social work). Due to page constraints, professional organizations whose purpose is to support teaching within a discipline (e.g., National Science Teachers Association, National Council for History Education) were not included, nor were organizations for professional studies (e.g., medicine, dentistry, veterinary science, nursing, clinical sciences, engineering). See Appendix A for a summary of the professional organizations and their learning resources. 


\section{Review of Professional Organizations}

\subsection{Arts and Humanities}

The five dimensions of critical thinking in the arts have been identified as perception, conception, expression, reflection, and re-vision (Eisner 1994, Siegesmund 2000). Therefore, the teaching of critical thinking in the arts and humanities should strive to address one or more of these dimensions. Many of the resources provided by the arts and humanities organizations summarized below can be directly applied to developing student's critical thinking skills.

\subsection{American Historical Association (AHA)}

The AHA promotes the study of history, preservation of artifacts and publication of historical research. In 1974, the Teaching Division was established to develop and promote teaching programs and resources.

1.1.1 Learning resource reviewed: Perspectives

(http://www.historians.org/perspectives/). This online journal provides articles on teaching and the use of computers and software in history. The archives are searchable and articles are available to non-members.

1.1.2 Sample article: Surfing for the past: how to separate the good from the bad (Schrum 2003). This article presents ways in which students can use critical thinking to evaluate the validity and reliability of online resources. Students are introduced to a resource called History Matters and are required to question and examine their sources. The author concludes that this approach "present a valuable opportunity-to teach critical thinking skills in the context of making effective use of Internet resources" (Schrum 2003).

\subsection{American Philosophical Society (APA)}

The APA promotes the exchange of ideas among philosophers, encourages creative and scholarly activity in philosophy and facilitates the work of teachers of philosophy.

1.2.1 Learning resource reviewed: Committee on the Teaching of Philosophy (http://www.apa.udel.edu/apa/governance/committees/teaching/orc/index .html). This APA Committee emphasizes the importance of "the cultivation of students' analytical, critical, interpretive and evaluative abilities in thinking about a variety of kinds of problems, historical texts, and issues, both "philosophical" and commonplace" (Schacht and Iseminger 1995). The Committee maintains a collection of course syllabi from all areas of philosophical study; a "What Works" database (short descriptions of successful classroom practices); and discussion boards on a variety of teaching topics. They also publish a biannual Newsletter on Teaching Philosophy. Recent articles are only available to members, but 1995-2001 newsletters are available for free.

1.2.2 Sample article: Teaching philosophy with argumentation maps (Horn 2000). The use of argumentation maps, an instructional tool that provides a representation of how critical discussions can take place across disciplinary and geographic distances, is discussed. Argumentation maps are intended to help students learn to think critically; students must evaluate the "weight" of the arguments and evidence and then draw their own conclusions.

\subsection{Modern Language Association (MLA)}

The MLA of America provides opportunities for its members to share their scholarly findings and teaching experiences with colleagues and to discuss trends in the 
1.3.1 Learning resource reviewed: What's the Word?

(http://www.mla.org/radio/). This radio show was developed to enhance the teaching of language and literature. Each installment has discussion questions and other possible learning activities. The radio shows can provide the basis for critical thinking activities that involve dialogical/dialectical thought, which according to Paul refers to students' abilities to "enter into thoughts and feelings other than their own" (Paul 1987). The programs cover a wide range of topics and the archives are searchable.

1.3.2 Sample radio show: Famous speeches (Packer et al. 2004). This show presents three speeches that shaped American history: Ralph Waldo Emerson's 1837 Phi Beta Kappa address; Frederick Douglass's 1852 "Fourth of July" oration about slavery; and Abraham Lincoln's Second Inaugural Address. Strategies to promote critical thinking on the issues raised are offered and students are encouraged to imagine alternative futures had these three men not been the orators that they were.

\subsection{National Council for Teachers of English (NCTE)}

The NCTE is devoted to improving the teaching and learning of English and the language arts at all levels of education.

1.4.1 Teaching resource reviewed: Read-Write-Think (http://www.readwritethink.org/). Read-Write-Think provides instructors with pedagogically sound resources for teaching reading and language arts, many involving the use of critical thinking skills. The lessons are geared towards K-12, but many of the high school lessons can be used as is or modified for lower-level undergraduate courses.

1.4.2 Sample lesson: A biography study: using role-play to explore authors' lives (Gibson and Coffey 2004). Students read biographies and explore websites of selected American authors. They collaborate in teams to design creative projects and role-play as the authors in a panel presentation. They then synthesize their knowledge into essays about their authors to post online.

\subsection{National Endow ment for Humanities (NEH)}

Although the NEH is not technically a professional organization, it is a large, national organization that represents the humanities. The NEH supports research, education, preservation, and public programs in the humanities. They fund programs to strengthen teaching and learning in the humanities in schools and colleges across the nation.

1.5.1 Teaching resource reviewed: EDSITEment

(http://edsitement.neh.gov/). Teaching resources from museums, libraries, cultural institutions, and universities are provided. The materials have been reviewed for educational impact and cover a wide range of humanities subjects. Each lesson is complete with learning objectives, suggested activities and assessment of student learning. The lessons are geared towards K-12, but many of the high school lessons can be used as is or modified for lower-level undergraduate courses.

1.5.2 Sample lesson: African-American soldiers in World War I: the 92nd and 93rd divisions (EDSITEment 2003). Students must conduct research in order to evaluate contradictory statements about the performance of the 92nd Infantry Division in World War I. Skills required include research and analysis, critical thinking, the ability to make inferences, draw conclusions and the work collaboratively.

\subsection{BUSI NESS}

The teaching of critical thinking skills is imperative across the business curriculum, since graduates must be prepared to make rapid decisions in a constantly changing world. McEwen (1999) found the most effective methods for encouraging critical 
thinking in business students were practical task completion, case studies and argumentative essays. Braun (2004) suggests that the development of critical thinking skills should be explicitly stated as a student learning outcome, instructors should model the skills they are trying to inspire and students should be presented with ample active learning activities involving the course content. Many professional organizations for business practitioners provide resources amenable with these approaches.

\subsection{American Economics Association (AEA)}

The AEA supports economic research, publishes on economic subjects and encourages the discussion of economic issues. A Committee on Economic Education has a mission is to improve the quality of economics education at all levels.

2.1.1 Learning resource reviewed: Journal of Economic Education (http://www.indiana.edu/ econed/). This journal offers original articles on innovations and evaluations of teaching techniques, materials and programs in economics. Articles address instruction at introductory levels through graduate economics and cover content and pedagogy in a variety of media.

2.1.2 Sample article: Teaching critical thinking with electronic discussion (Greenlaw and DeLoach 2003). Based on an evaluation of critical thinking research, the authors developed a scale for assessing student critical thinking skills within the context of online discussion activities, focusing on "how students argue". Their evaluative scale has six levels ranging from "unilateral decisions" (little or no critical thinking) to "merging values with analysis" (the highest level of critical thinking). Instructors across disciplines should find this scale useful and adaptable for evaluating their own student's critical thinking skills in online discussions.

\subsection{American Institute of Certified Public Accountants (AI CPA)}

The AICPA is the professional organization for Certified Public Accountants. The organization has established a Core Competency Framework that identifies a set of competencies needed by all students entering the accounting profession. These include, among other things, "strategic and critical thinking".

2.2.1 Learning resource reviewed: Accounting Education Center (http://ceae.aicpa.org/). The Center provides resources to enhance accounting and business instruction, including a model tax curriculum, a collection of 100 case studies, student exercises and a teaching kit. The case studies can be searched based on Core Competencies.

2.2.2 Sample case study: A strategy-focused CPA firm (Frasier et al. 2001). Students are required to develop management strategies and decision-making skills using realistic situations faced by many CPA firms. AICPA members have direct access a solution sheet online; instructors who are non-members can contact the AICPA and request a copy.

\subsection{American Marketing Association (AMA)}

The AMA is one of the largest professional associations for marketers and is the leading source for information, knowledge sharing and development in the marketing profession.

2.3.1 Learning resource reviewed: Academic Resource Center (ARC) (http://www. marketingpower.com/content4282.php).

The ARC website provides links to case studies, course syllabi and other course materials. A regular feature on the website is Teachable News, which provides learning activities based on recent news stories. Each entry provides a link to the story, important concepts and discussion questions. 2.3.2 Sample news story: Orchard Music rides the long tail of consumer preference (AMA 2006). This teachable news was inspired by a story about the marketing of songs to be played on the Internet. Orchard Music makes money selling a small number of copies of millions of songs. Students must 
use critical thinking skills to evaluate this real-world issue and to make marketing decisions based on analysis of information presented.

\subsection{Council of Supply Chain Management Professionals (CSCMP)}

CSCMP is the professional association of Supply Chain Management professionals. The organization has an Education Strategies Committee that acts as a liaison with students, educators and educational institutions. This committee is responsible for an annual education conference, logistic education materials, and a database of case studies.

2.4.1 Learning resource reviewed: Case studies (http://www.cscmp.org/Website/Resources/CaseStudy.asp). The use of case studies is a widely used instructional approach that exposes students to challenging logistical issues and encourages them to develop their critical thinking and decision-making skills. Each case study has associated Teaching Notes with suggested learning activities and student assessment.

2.4.2 Sample case study: Moving mountains at Marks and Spencer (Christopher and Peck 2000). Students are placed in a retail clothing company as part of the global logistics team. The company has recently suffered a major scandal and the students must identify key areas for attention and offer suggestions as to how to implement a reorganization of the company's global logistics.

\subsection{I nstitute of Management Accountants (I MA)}

The IMA serves managers and administrators in management accounting and financial management. They are committed to the development and support of education products related to management accounting. The Academic Industry Sector is a special interest group whose mission is to promote sharing of ideas, experiences and knowledge among members in academia.

2.5.1 Teaching resource reviewed: Cases from Management Accounting Practices

(http: //www.imanet.org/ima/sec. asp?TRACKID $=\& C I D=761 \& D I D=965$ ).

The IMA publishes cases and teaching notes. Instructors can access these cases online and non-members can request teaching notes.

2.5.2 Sample case study: Bill's custom planters (Stammerjohn and Seifert 2001). Students have to analyze a company with staffing and cash flow problems using a holistic approach. They must examine production and cash flow projections, develop pro forma statements and conduct a sensitivity analysis.

\subsection{EDUCATI ON}

Teacher education programs must prepare teachers to model the skills they seek to inspire in their students, including higher order skills such as reasoning, complex problem solving and critical thinking. Accreditation standards and licensure requirements emphasize the importance of critical thinking in teacher education programs. Yet as recently as three years ago, Linda Elder stated in an interview that "critical thinking is not typically a significant part of teacher preparation programs" because critical thinking is not typically understood, either in schools or in the broader society (Shaughnessy and Seevers 2003). To correct this deficiency, teacher education programs have been encouraged to include the goals and their philosophy for the teaching of critical thinking, the definition of critical thinking, the preparation of college faculty to teach for critical thinking and the development of new curricula in the undergraduate program (Michelli et al. 1990). Now, in many pre-teacher courses, case-based instruction is being used to develop students' critical thinking, problem solving and reflective decision making skills. Most of the professional organizations within education deal directly with the support of teaching and learning. As stated in the Introduction, these organizations were not reviewed since it is implicit in their mission to provide instructional support. 


\subsection{National Education Association}

The NEA is the nation's largest professional employee organization and is committed to advancing the cause of public education. The "In the Classroom" section of their website features lesson plans, approaches to dealing with classroom management, a sharing of classroom experiences and a free electronic newsletter called "Works4Me".

3.1.1 Teaching resource reviewed: Lesson Ideas (http://www.nea.org/lessons/index.htmlx). This resource provides hundreds of lesson plans that may be searched by key word or discipline. For example, a search using "critical thinking" turned up 27 lessons. Significantly more lessons could used to promote critical thinking and the best approach would be to search by discipline. Learning objectives, activities, assessment tools and other supporting materials are provided in most of the lessons.

3.1.2 Sample lesson: Use editorial cartoons to teach about elections (McKenzie 2004). Political cartoons have a long history and can be a good tool for teaching higher-level thinking skills; students can analyze them and express how they make them feel towards a subject. This lesson suggests a number of approaches for the use of editorial cartons in all types of disciplines. Additional resources provide background information about political cartoons and links to cartoon databases.

\subsection{NATURAL AND LIFE SCIENCES}

Scientific teaching demands active learning strategies to engage students in the process of science and to develop their scientific reasoning. Handelsman et al. (2004) emphasize the use of problem-based learning, case studies, group problemsolving in lectures, inquiry-based laboratory exercises and interactive computer learning as ways to prepare all students to use scientific thinking to address complex societal issues. Not surprisingly, due to the nature of science, excellence in science teaching focuses on the development of students' critical thinking skills. Bransford et al. (2002) said "one way to help students develop critical thinking skills is to focus on problems or cases where they are challenged to deal with real data and experiences". The resources that follow all address the need of using studentcentered, active-learning lessons in teaching science.

\subsection{American Association for the Advancement of Science (AAAS)}

The AAAS is dedicated to advancing science around the world by serving as an educator, leader, spokesperson and professional association. They offer a variety of resources for science educators, many of which contain approaches to teaching and encouraging critical thinking.

4.1.1 Learning resource reviewed: BioSciEdNet

(http://www. biosciednet.org/portal/). This is a searchable database that provides seamless access to a digital library collection of accurate and reliable biology science education resources. The materials represent a broad spectrum of biological science disciplines.

4.1.2 Sample article: Team-based learning enhances long-term retention and critical thinking in an undergraduate microbial physiology course (Mclnerney and Fink 2003). This article presents a team-based learning approach that has been shown to significantly improve student performance as measured by comprehension and retention of information, critical thinking and attitudes about the course.

\subsection{American Physiological Society}

The APS serves physiologists and those in related health professions. Its purpose is to support education, scientific research and dissemination of information in the physiological sciences. The Teaching of Physiology Section of the APS is responsible for matters relevant to physiology teaching in undergraduate, graduate, and 
professional education. The APS offers online teaching resources, including lessons and laboratories, scientific background and review papers, tools for better teaching and learning, and technology-based resources for interactive, online teacher and student development.

4.2.1 Learning resource reviewed: Archive of Teaching Resources (http://www.the-aps.org/education/edu teachingres. html).

This resource allows you to search for teaching materials by education level, topic, media type, and most importantly, by pedagogies (e.g., casebased/case study approach, critical analysis/critical thinking). All of the lessons have been reviewed and tested; many of them have been published in peer-reviewed journals.

4.2.2 Sample lesson: Student critical thinking is enhanced by developing exercise prescriptions using online learning modules (Brahler et al. 2002). This article describes online learning modules designed to promote higherorder critical thinking skills in students enrolled in an exercise physiology course. The modules require students to review clinical physiological details from authentic patient case data and develop exercise prescriptions.

\subsection{Ecological Society of America (ESA)}

The ESA is the premiere professional organization for ecologists in the US. The Education Section of the society provides resources for ecological education for students of all ages and disseminates instructional materials and pedagogic ideas. 4.3.1 Teaching resource reviewed: Pathways to Scientific Teaching (http://www.first2.org/resources/frontiers/scientific teaching first.html). This is a series in the journal Frontiers in Ecology and the Environment in which a teaching and learning unit is presented based on a research paper (also published in the same issue). Each learning unit contains explicit learning goals, instructional strategies and a means for assessing student learning. The goal of these lessons is to ensure that students understand the key scientific principles, demonstrate basic scientific skills and are able to exercise logical thought in applying these principles and skills.

4.3.2 Sample lesson: Lyme disease: a case about ecosystem services (Richmond et al. 2005). This lesson is a case study designed to demonstrate how a number of disciplines are often necessary to inform ecological decision-making. Students use a team approach to develop a management strategy to control the spread of ticks infected with the Lyme disease vector using information from scientific sources. They must be able to recognize the relationship among ecosystem services, biodiversity, functional diversity, community disassembly and landscape ecology.

\subsection{Mathematical Association of America (MAA)}

The MAA is the largest professional society that focuses on mathematical science. One of their missions is to support student learning by encouraging an effective mathematics curriculum, teaching and assessment. The AMA website offers a variety of teaching resources.

4.4.1 Teaching resource reviewed: MathDL (http://mathdl.maa.org/mathDL). MathDL is an online resource for both teachers and students of mathematics, and provide, among other things, Convergence (an online magazine about teaching math using its history) and Digital Classroom Resources (DCR). Teaching materials at the DCR website include interactive web pages, web pages enhanced with animation, downloadable programs that run independently and modules developed for commercial computer algebra systems. Open Source Shareable Mathlets or Osslets are a visual tool for teaching complex mathematical concepts and a collection of Osslets is accessible on the DCR website.

4.4.2 Sample resource reviewed: Mulitparameter Animation Osslet (Moores and Wattenberg 2004). This Osslet can be used to investigate and 
animate up to three functions involving up to four parameters. Information provided with all Osslets includes an overview, how it can be used, how it can be integrated into a course unit and additional resources for instructors.

\subsection{National Athletic Trainer's Association (NATA)}

The mission of the NATA is to enhance the quality of health care provided by board certified athletic trainers and to advance the athletic training profession. Within the association, the Education Council's focus is to ensure excellence in undergraduate, graduate and continuing athletic training education.

4.5.1 Learning Resource reviewed: Journal of Athletic Training (http://www.nata.org/jat/). The mission of this journal is to enhance the exchange of ideas among professionals involved in health of physically active individuals. A section called "Educational Studies" is frequently included and contains papers that address issues of athletic training education.

4.5.2 Sample Article: Active learning strategies to promote critical thinking (Walker 2003). A number of active learning strategies for use in athletic training courses are presented, including questioning, written exercises, discussion and debates. The definition of critical thinking, the disposition to think critically and specific examples of these teaching strategies are featured.

\subsection{SOCI AL SCI ENCES}

In the social sciences, critical thinking is typified by the ability to recognize central issues, make comparisons, differentiate relevant information from non-relevant, ask the right questions, articulate problems, distinguish fact from opinion, check consistency, ascertain assumptions, identify bias, investigate cause and effect and demonstrate reasoned judgment (Barell et al.1992). Teaching strategies to develop these skills include student engagement in reading, writing, observation, debates, role play and simulations. Individual or collaboratively, social science students should be required to use statistical data to cultivate skills in critical thinking, decision making, and problem solving.

\subsection{Academy of Criminal J ustice Sciences (ACJ S)}

The ACJS fosters professional and scholarly activities in the field of criminal justice and promotes criminal justice education, research, and policy analysis within the discipline.

5.1.1 Learning resource reviewed: J ournal of Criminal J ustice Education (http://www.acjs.org/pubs/167 669 2917.cfm).

This journal provides a forum for the examination, discussion and debate of a broad range of issues concerning education in criminal justice, criminology and related areas.

5.1.2 Sample article: Generating enthusiasm for undergraduate research by teaching futures-based problem-solving skills (Bolton 2000).

Students in this activity are encouraged to think about important issues related to criminal justice and sociology and predict the impact of these issues in the future.

\subsection{American Political Science Association (APSA)}

The APSA is the leading professional organization for the study of political science. A component of this organization's mission is to support political science education and professional development of its members.

5.2.1 Learning resource reviewed: Annual Teaching and Learning Conference (http://www.apsanet.org/section_236.cfm). This annual conference promotes sharing of innovative teaching practices in the political science classroom and many presentations discuss instructional approaches that 
encourage critical thinking. Papers presented at each of the annual meetings can be searched and downloaded for free.

5.2.2 Sample article: Effect of congressional role-playing experience on students (Chin 2006). This article presents research on the effectiveness of integrating CQ Legislative Simulation into a course that teaches students about political action committees and constituency status. The author concludes that any active learning approach must "create opportunities for students to develop problem-solving and critical analytical thinking skills" (Chin 2006).

\subsection{American Psychological Association (APA)}

The APA represents psychologists in the United States. The Education Directorate is tasked to advance education and training in psychology. The Society for the Teaching of Psychology (STP), a division within the directorate, supports and disseminates pedagogical strategies for teaching psychology. The STP publishes a quarterly journal (Teaching Psychology), presents teaching awards, sponsors conferences, maintains a website that provides materials related to the teaching of psychology and provides several E-publications.

5.3.1 Learning resource reviewed: Essays from E-xcellence in teaching (http://teachpsych.lemoyne.edu/teachpsych/eit/). This E-publication is an annual compendium of invited essays which were originally published in PsychTeacher, a moderated discussion list sponsored by the STP.

5.3.2 Sample article: Teaching psychology students to distinguish science from pseudoscience: pitfalls and rewards (Lilienfeld 2004). The premise of this article is that the best approach to teaching critical thinking skills in psychology is to expose students to fallacies, especially those that fall under the rubric of pseudoscience. The author outlines an approach to teach students how to differentiate between science and pseudoscience.

\subsection{American Sociological Association (ASA)}

The ASA is dedicated to advancing sociology as a scientific discipline. The Section on Teaching and Learning in Sociology provides a professional venue for improving the teaching of sociology from high school through the graduate level.

5.4.1 Learning resource reviewed: Teaching Sociology (http://www2.asanet.org/sectionteach/). This journal disseminates innovative and effective pedagogy in the instruction of sociology. Notes focus on specific teaching issues or techniques, many of which have been shown to improve students' critical thinking skills.

5.4.2 Sample article: Introducing methods of sociological inquiry using living-data exercises (Rohall et al. 2004). This article discusses the use of "living data exercises" to introduce students to social science methods. Students take on roles as either the investigator or the subject while collecting data in class. Afterwards, students reflect upon the process from multiple perspectives.

\section{Conclusions}

The diversity of instructional materials available from professional organizations is immense, as is the quality of these materials. But how can instructors make good use of these disciplinespecific lessons and teaching resources in developing their students' critical thinking skills? Paul (1995) suggests that there are five basic components in the teaching of critical thinking. The first is the instructor, who must be able to reduce big questions or

The diversity of instructional materials available from professional organizations is immense, as is the quality of these materials. 
problems into approachable tasks, contextualize learning, help students focus their thinking, require students to integrate and synthesize information, require that students teach each other difficult concepts, and teach students how to find, evaluate and access learning resources. The second component involves the use of Socratic questioning to introduce basic issues, encourage students to think deeper, focus on topics that the students struggle with, and develop skills related to sensitivity, clarity, accuracy and relevance. The third involves the use role-playing and reconstruction of opposing views. The fourth component is the requirement that students reflect and analyze their own experiences within a global context. The final component is to teach the difference between fact, opinion and reasoned judgment. Instructors should keep these components in mind when developing their own course learning activities.

Designing and integrating instructional activities to teach students critical thinking can be hard, especially when lectures, rote memorization and the use of multiple choice tests are easy. Yet there are a number of types of learning activities that can be used to encourage critical thinking, such as guided discussion, debates, role-playing, problem-solving, case studies, group projects, simulations, model building, project design, performances, presentations, experiments, research, and interviews (see Peirce 2004 for examples of these types of activities specifically designed to address critical thinking). The lessons and teaching resources reviewed in this paper are representative of these forms of activities and many of them can be directly integrated into courses without much modification. Some instructors may want to share specific activities with their institutional teaching support center for suggestions on suitability, modifications or improvements. In addition, instructors should consider explicitly informing their students on the purpose of the activity as related to critical thinking (e.g., this lesson is designed to improve your self-confidence and maturity through interpretation, inference and self-regulation). Finally, instructors must not neglect the importance of assessment. The Critical Thinking Project at Washington State University offers an excellent rubric for assessing critical thinking (WSU 2006). It addresses a student's ability to identify and summarize the problem/issue; identify and present their own hypothesis, perspective and position; identify and consider other perspectives; identify and assess key assumptions; identify and assess the quality of their supporting data/evidence; identify and consider the influence of context on the issue; and identify and assess their conclusions, implications and consequences. Peirce (2006) provides a summary of how to write rubrics for critical thinking assessment and also presents a compilation of rubrics created by others.

Teaching critical thinking skills to students should not put an undue burden on instructors; there is ample instructional support available through usual academic channels, such as campus-based teaching and learning centers, as well as the not so usual channels; discipline-specific professional organizations.

\section{References}

[AMA] American Marketing Association. 2006. Orchard Music rides the long tail of consumer preference. Teachable News.

Available from:

http://www. marketingpower.com/

content32156.php. Accessed 28

March 2006.
Barell J, Drake F, McBride L. 1992. A History of the United States, American Voices: Critical Thinking

Activities. Glenview, IL: Scott

Foresman and Company; $169 \mathrm{p}$. 
Bolton MJ . 2000. Generating enthusiasm for undergraduate research by teaching futures-based problem-solving skills. Journal of Criminal J ustice 11: 123-133.

Brahler CJ, Quitadamo IJ, J ohnson EC. 2002. Student critical thinking is enhanced by developing exercise prescriptions using online learning modules. Advances in Physiology Education 26: 210-221.

Bransford J, Vye N, Bateman H. 2002. Creating high-quality learning environments: guidelines from research on how people learn. In: Graham PA, Stacey NG, editors. The Knowledge Economy and Postsecondary Education: Report of a Workshop. Washington, DC: National Academy Press; 216 p.

Braun NM. 2004. Critical thinking in the business curriculum. Journal for Education for Business March/April: 232-236.

Chin M. 2006. Effect of congressional role-playing experience on students' attention to constituency \&

PACs. Paper presented at the annual meeting of the APSA Teaching and Learning Conference, Washington, DC. Available from:

http://convention2.allacademic.com/ index.php?cmd=Download+Documen t\&key=unpublished_manuscript\&file index $=1 \&$ pop_up =true\&attachment style $=$ attachment\&PHPSESSID $=522 \mathrm{c}$ 6a28ae5f67c5715aab59bca4b19b. Accessed 30 March 2006.

Christopher M, Peck H. 2000. Moving mountains at Marks and Spenser. CSCMP Case Studies. Available from: http://www.cscmp.org/Downloads/Ca seStudy/ms.pdf. Accessed 28 March 2006.

Cotton K. 1991. Teaching thinking skills: close-up No. 11. School Improvement Research Series. Portland, OR: Northwest Regional Educational Laboratory. Available from: http://www.nwrel.org/ scpd/sirs/6/cul1.html. Accessed 30 March 2006.

InSight: A Collection of Faculty Scholarship
EDSITEment. 2003. African-American soldiers in World War I: the 92nd and 93rd divisions. EDSITEment Lesson Plan. Available from: http://edsitement.neh.gov/view_less on plan.asp? id=497. Accessed 28 March 2006.

Eisner EW. 1994. Cognition and Curriculum Reconsidered. 2d ed. New York: Teachers College Press; 107 p.

Ennis RH. 1990. The extent to which critical thinking is subject-specific: further clarification. Educational Researcher 19: 13-16.

Facione PA. 2006. Critical thinking: what it is and why it counts - 2006 update. InSight Assessment. Millbrae, CA: California Academic Press; 21 p. Available from: http://www.InSightassessment.com/ pdf files/what\&why2006.pdf Accessed 30 March 2006.

Frasier CE, Allen D, Morgan DK. 2001. A strategy-focused CPA firm. Case No. 2001-10. AICPA Case Development Program. Available from:

http://ftp.aicpa.org/public/download/ members/ div/career/edu/200110a_Strategy Focused.pdf. Accessed 31 March 2006.

Gibson CSA, Coffey DJ . 2004. A biography study: using role-play to explore authors' lives. Read-WriteThink Lesson. Available from: http://www.readwritethink.org/lesso ns/lesson view.asp? id=398. Accessed 31 March 2006.

Greenlaw SA, DeLoach SB. 2003. Teaching critical thinking with electronic discussion. Journal of Economic Education 34: 36-52.

Handelsman J, Ebert-May D, Beichner R, Bruns $P$, Chang A, DeHaan R, Gentile J, Lauffer S, Stewart J, Tilghman SM, Wood WB. 2004 Scientific teaching. Science 304: 52 53. 
Horn RE. 2000. Teaching philosophy with argumentation maps. Newsletter on Teaching Philosophy. 00:1.

Available from:

http://www.apa.udel.edu/apa/publica tions/newsletters/

v00n1/teaching/03.asp. Accessed 30 March 2006.

Huitt W. 1998. Critical thinking: an overview. Educational Psychology Interactive. Valdosta, GA: Valdosta State University. Available from: http://chiron.valdosta.edu/whuitt/col /cogsys/ critthnk.html. Accessed 30 March 2006. [Revision of paper presented at the Critical Thinking Conference sponsored by Gordon College, Barnesville, GA; March 1993.]

Lilienfeld SO. 2004. Teaching psychology students to distinguish science from pseudoscience: pitfalls and rewards. In: Saville BK, Zinn TE, Hevern VW, eds. Essays from Excellence in Teaching. Society for the Teaching of Psychology. Available from:

http://teachpsych. lemoyne.edu/teach psych/eit/eit2004/eit04-06.html. Accessed 29 March 2006.

McEwen BC. 1994. Teaching critical thinking skills in business education. J ournal of Education for Business 70 : 99-103.

Mclnerney MJ , Fink LD. 2003. Teambased learning enhances long-term retention and critical thinking in an undergraduate microbial physiology course. Microbiology Education Journal 4: 3-12.

McKenzie W. 2004. Use editorial cartoons to teach about elections. EducationWorld.com. Available from: http://www. nea.org/lessons/2004/tt0 41101.html. Accessed 28 March 2006.
Michelli, NM, Pines P, Oxman-Michelli W. 1990. Collaboration for critical thinking in teacher education: the Montclair State College model. Institute for Critical Thinking Resource Publication. Series 3 No. 3. Upper Montclair, NJ: Institute for Critical Thinking; 19 p. Available from:

http://eric.ed.gov/ERICWebPortal/co ntentdelivery/servlet/ERICServlet?ac $\mathrm{cno}=\mathrm{ED} 353214$. Accessed $31 \mathrm{March}$ 2006.

Moores K, Wattenberg F. 2004. Multiparameter animation. Digital Classroom Resources. Mathematical Association of America. Available from:

http://mathdl.maa.org/mathDL/ 3/?pa=content\&sa =viewDocument\&n odel $d=1059 \& b o d y l d=1248$. Accessed 29 March 2006.

Packer B, Blight D, Burt J . 2004. Famous speeches. What's the Good Word? Radio Show No.171. Modern Languages Association. Available from:

http://www.mla.org/radio_show 6. Accessed 31 March 2006.

Paul R. 1987. Dialogical thinking: critical thought essential to the acquisition of rational knowledge and passions. In: Baron JB, Sternberg RJ, editors. Teaching Thinking skills: Theory and Practice New York: W.H. Freeman; pp. 127-148.

Paul R. 1995. Critical thinking: how to prepare students for a rapidly changing world. Santa Rosa, CA: Foundation for Critical Thinking; 572 p.

Paul R, Elder L, Bartell T. 1997. California teacher preparation for instruction in critical thinking: research findings and policy recommendations. Sacramento, CA: California Commission on Teacher Credentialing; 184 p. Available from: http://www.criticalthinking.org/resou rces/books/california-teacherpreparation.shtml. Accessed 19 June 2006. 
Peirce W. 2006. Designing rubrics for assessing higher order thinking.

Association of Faculties for

Advancement of Community College

Teaching, Howard University, January 2006. Available from:

http: //academic.pg.cc.md.us/ wpeir ce/MCCCTR/Designingrubricsassessin gthinking.html. Accessed 25 May 2006.

Peirce W. 2004. Handbook of critical thinking resources. Prince George's Community College. Available from: http://academic. pgcc. edu/\% 7Ewpeirc e/MCCCTR/handbook.pdf. Accessed 25 May 2006.

Raths LE, Jonas A, Rothstein A, Wassermann, S. 1967. Teaching for Thinking, Theory and Application. Columbus, $\mathrm{OH}$ : Charles E. Merrill; $348 \mathrm{p}$.

Richmond C, Ebert-May D, Hodder J. 2005. Lyme disease: a case about ecosystem services. Frontiers in Ecology and the Environment 3: 557 558.

Rohall DE, Brown C, Moran CL, Caffrey E. 2004. Introducing methods of sociological inquiry using livingdata exercises. Teaching Sociology 32: 401-407

Schacht R, Iseminger G. 1995. The teaching of philosophy. Proceedings and Addresses of the American Philosophical Association 69: 96-100.
Schrum K. 2003. Surfing for the past: how to separate the good from the bad. Perspectives 41:5/ May 2003. Available from: http://www.historians.org/perspectiv es/issues/2003/0305/0305for3.cfm. Accessed 30 March 2006.

Shaughnessy MF, Severs R. 2003. An interview with Linda Elder: about critical thinking and gifted education. The Critical Thinking Community. Available from:

http://www.criticalthinking.org/ resources/articles/an-interview-lindaelder.shtml. Accessed 30 March 2006.

Siegesmund R. 2000. Reasoned perception: art education at the end of art. Ph.D. Dissertation. Stanford University.

Stammerjohn W, Seifert D. 2001. Bill's custom planters. Cases from Management Accounting Practice 15: 19-25. Available from: http://www.imanet.org/ima/docs/150 0/1438.pdf. Accessed 29 March 2006.

Walker SE. 2003. Active learning strategies to promote critical thinking. Journal of Athletic Training 38: $263-267$.

[WSU] Washington State University. 2006. Critical Thinking Rubric. The Critical Thinking Project. Available from:

http:// wsuctproject.wsu. edu/ctr.htm. Accessed 25 May 2006.

Bowers received her $\mathrm{PhD}$ in Ecology from the Pennsylvania State University, where she studied the evolutionary relationships among a group of closely related cichlid fishes. She has since taught biology at Portland State University, Idaho State University and now online at Park University. In addition to her research and teaching interests, Bowers has also been involved in faculty development. She lives in northern New York and has been teaching for Park University since 2005. 


\begin{tabular}{|c|c|c|}
\hline Organization & Discipline & Learning Resource \\
\hline \multicolumn{3}{|l|}{ Arts and Humanities } \\
\hline $\begin{array}{l}\text { American Historical } \\
\text { Association }\end{array}$ & History & $\begin{array}{l}\text { Perspectives } \\
\text { (http://www.historians.or } \\
\text { g/perspectives/) }\end{array}$ \\
\hline $\begin{array}{l}\text { American Philosophical } \\
\text { Society }\end{array}$ & Philosophy & $\begin{array}{l}\text { Committee on the } \\
\text { Teaching of Philosophy } \\
\text { (http://www.apa.udel.edu } \\
\text { /apa/governance/committ } \\
\text { ees/teaching/orc/index.ht } \\
\text { ml) }\end{array}$ \\
\hline Modern Language Association & $\begin{array}{l}\text { Modern } \\
\text { languages }\end{array}$ & $\begin{array}{l}\text { What's the Word? } \\
\text { (http://www.mla.org/radi } \\
\text { o/) }\end{array}$ \\
\hline $\begin{array}{l}\text { National Council for Teachers } \\
\text { of English }\end{array}$ & English & $\begin{array}{l}\text { Read-Write-Think } \\
\text { (http://www.readwritethi } \\
\text { nk.org/) }\end{array}$ \\
\hline $\begin{array}{l}\text { National Endowment for } \\
\text { Humanities }\end{array}$ & Humanities & $\begin{array}{l}\text { EDSITEment } \\
\text { (http://edsitement.neh.g } \\
\underline{\underline{\text { ov/l) }}}\end{array}$ \\
\hline \multicolumn{3}{|l|}{ BUSI NESS } \\
\hline $\begin{array}{l}\text { American Economics } \\
\text { Association }\end{array}$ & Economics & $\begin{array}{l}\text { Journal of Economic } \\
\text { Education } \\
\text { (http://www.indiana.edu/ } \\
\text { 〜econed/) }\end{array}$ \\
\hline $\begin{array}{l}\text { American Institute of } \\
\text { Certified Public Accountants }\end{array}$ & Accounting & $\begin{array}{l}\text { Accounting Education } \\
\text { Center } \\
\text { (http://ceae.aicpa.org/) }\end{array}$ \\
\hline $\begin{array}{l}\text { American Marketing } \\
\text { Association }\end{array}$ & Marketing & $\begin{array}{l}\text { Academic Resource } \\
\text { Center } \\
\text { (http://www.marketingpo } \\
\text { wer.com/content4282.ph } \\
\text { p) }\end{array}$ \\
\hline $\begin{array}{l}\text { Council of Supply Chain } \\
\text { Management Professionals }\end{array}$ & $\begin{array}{l}\text { Supply Chain } \\
\text { Management }\end{array}$ & $\begin{array}{l}\text { Case studies } \\
\text { (http://www.cscmp.org/ } \\
\text { Website/Resources/Cases } \\
\text { tudy.asp) }\end{array}$ \\
\hline $\begin{array}{l}\text { Institute of Management } \\
\text { Accountants }\end{array}$ & Management & $\begin{array}{l}\text { Cases from Management } \\
\text { Accounting Practices } \\
\text { (http://www.imanet.org/i } \\
\text { ma/sec.asp?TRACKID=\&C } \\
\underline{\mathrm{ID}=761 \& D I D=965)}\end{array}$ \\
\hline \multicolumn{3}{|l|}{ EDUCATION } \\
\hline $\begin{array}{l}\text { National Education } \\
\text { Association }\end{array}$ & Education & $\begin{array}{l}\text { Lesson Ideas } \\
\text { (http://www.nea.org/less } \\
\text { ons/index.htmlx) }\end{array}$ \\
\hline \multicolumn{3}{|l|}{ NATURAL AND LIFE SCIENCES } \\
\hline American Association for the & Science & BioSciEdNet \\
\hline
\end{tabular}




\begin{tabular}{|c|c|c|}
\hline Advancement of Science & & $\begin{array}{l}\text { (http://www. biosciednet. } \\
\text { org/portal/) }\end{array}$ \\
\hline $\begin{array}{l}\text { American Physiological } \\
\text { Society }\end{array}$ & Physiology & $\begin{array}{l}\text { Archive of Teaching } \\
\text { Resources } \\
\text { (http://www.the- } \\
\text { aps.org/education/edu_te } \\
\text { achingres.html) }\end{array}$ \\
\hline Ecological Society of America & Ecology & $\begin{array}{l}\text { Pathways to Scientific } \\
\text { Teaching } \\
\text { (http://www.first2.org/re } \\
\text { sources/frontiers/scientifi } \\
\text { c_teaching_first.html) }\end{array}$ \\
\hline $\begin{array}{l}\text { Mathematical Association of } \\
\text { America }\end{array}$ & Mathematics & $\begin{array}{l}\text { MathDL } \\
\text { (http://mathdl.maa.org/ } \\
\text { mathDL) }\end{array}$ \\
\hline $\begin{array}{l}\text { National Athletic Trainer's } \\
\text { Association }\end{array}$ & Athletic Training & $\begin{array}{l}\text { Journal of Athletic } \\
\text { Training } \\
\text { (http://www.nata.org/jat/ }\end{array}$ \\
\hline \multicolumn{3}{|l|}{ SOCIAL SCI ENCES } \\
\hline $\begin{array}{l}\text { Academy of Criminal Justice } \\
\text { Sciences }\end{array}$ & Criminal J ustice & $\begin{array}{l}\text { J ournal of Criminal J ustice } \\
\text { Education } \\
\text { (http://www.acjs.org/pub } \\
\text { s/167_669_2917.cfm) }\end{array}$ \\
\hline $\begin{array}{l}\text { American Political Science } \\
\text { Association }\end{array}$ & Political Science & $\begin{array}{l}\text { Annual Teaching and } \\
\text { Learning Conference } \\
\text { (http://www.apsanet.org/ } \\
\text { section_236.cfm) }\end{array}$ \\
\hline $\begin{array}{l}\text { American Psychological } \\
\text { Association }\end{array}$ & Psychology & $\begin{array}{l}\text { Essays from E-xcellence } \\
\text { in Teaching } \\
\text { (http://teachpsych.lemoy } \\
\text { ne.edu/teachpsych/eit/) }\end{array}$ \\
\hline $\begin{array}{l}\text { American Sociological } \\
\text { Association }\end{array}$ & Sociology & $\begin{array}{l}\text { Teaching Sociology } \\
\text { (http://www2.asanet.org/ } \\
\text { sectionteach/) }\end{array}$ \\
\hline
\end{tabular}

